\title{
REGULATIONS ON ROAD VEHICLE NOISE - TRENDS AND FUTURE ACTIVITIES
}

\author{
Danijela Miloradović ${ }^{1}$, Jasna Glišović ${ }^{2}$, Jovanka Lukić ${ }^{3}$
}

UDC: $629 ; 534.292$

\section{INTRODUCTION}

It is universally acknowledged that noise is not only a huge ecological problem, but it represents an unpredictable danger to human health. This problem has been existing since forming of the huge cities and occurrence of the large number of engine operated vehicles on the city streets and roads. Thus, it is no surprise that only after three decades of existence of motorized transport, the British Government had introduced legislation to control the road vehicle noise, by a simple act, known as "The Motor Cars (Excessive Noise) Regulations, No. 416", passed in 1929. This act, adopted before the invention of any means of measuring noise, had authorized the police officers and courts to decide if the vehicle was too noisy [1].

Motor vehicle is a complex source of noise emission, made by equipping the vehicle with (internal combustion) engine. All surfaces of the vehicle's engine and chassis generate vibrations and sound waves, which are perceived as noise. Vehicle passengers hear the sum of all contributions from airborne noise and structure borne noise carried to the vehicle interior, joined by contributions from aerodynamic noise and tire rolling noise. In most cases, the passenger cannot distinguish different noise sources inside the vehicle. It can only be done by using corresponding measurement technique. However, drivers and passengers are not only exposed to noise originating from their own vehicles. Their environment also contains noise from all other vehicles participating in traffic.

Noise contributes to disorders of the cardiovascular, nervous and digestive system of the driver. It also has an adverse effect on the nervous system and induces stress and increased blood pressure. Excessive traffic noise damages driver's hearing and health. It frequently exceeds limit values set for occupational noise. This is particularly important for health of professional drivers, such as bus and truck drivers, who experience increased stress levels from the traffic and from their working schedules [2].

The European Parliament and the Council of Europe have adopted "Directive 2002/49/EC of the European Parliament and of the Council of 25 June 2002 relating to the assessment and management of environmental noise - Declaration by the Commission in the Conciliation Committee on the Directive relating to the assessment and management of environmental noise” in 2002. This Directive is also known as „END - Environmental Noise Directive“, and it applies to environmental noise to which humans are exposed in urban and rural areas. Its goal is "to define a common approach intended to avoid, prevent or reduce on a prioritised basis the harmful effects, including annoyance, due to exposure to

\footnotetext{
${ }^{1}$ Danijela Miloradović, Ph.D., assist. prof., University of Kragujevac, Faculty of engineering, 6 Sestre Janjić Str., 34000 Kragujevac, Serbia,neja@kg.ac.rs

${ }^{2}$ Jasna Glišović, Ph.D., assist. prof., University of Kragujevac, Faculty of engineering, 6 Sestre Janjić Str., 34000 Kragujevac, Serbia, jaca@kg.ac.rs

${ }^{3}$ Jovanka Lukić, Ph.D., prof., University of Kragujevac, Faculty of engineering, 6 Sestre Janjić Str., 34000 Kragujevac, Serbia, lukicj@kg.ac.rs
} 
environmental noise" [3]. In addition, END has a goal of providing a basis for developing community measures to reduce noise emitted by the major sources, one of them, in particular, being road vehicles.

Road traffic noise is the most prevalent environmental noise source in Europe. Estimations show that the overall number of people exposed to road traffic noise inside and outside urban areas amounts to around $24 \%$ of the total European population. This means that around 125 million people are likely to be exposed to threshold levels of road traffic noise according to the Environmental Noise Directive (END) 2002/49/EC. The threshold levels used for noise mapping and action planning by the END are $55 \mathrm{~dB}$ for the dayevening-night noise indicator, Lden, and $50 \mathrm{~dB}$ for the night-time noise indicator, Lnight [4, $5]$.

Road traffic noise emissions can be reduced at a source, via measures relating to vehicles, tyres, road surfaces and traffic management, or by reducing the exposure of people by means of anti-propagation or insulation measures. Most European Union (EU) regulations focus on mitigating noise at the source, such as: establishing limits for the noise of vehicle engines and exhausts, promotion of quieter tyres and development of low-noise road surfaces. Low-noise road surfaces have considerable potential to cut road noise and are complementary to technical measures that reduce engine, exhaust and tyre noise from passenger cars and larger vehicles [5].

In recent years, the requirements relating to the acoustics of the vehicle has increased, which is, on one hand, caused by the increase in user demands, and on the other hand, by development and trends in the automotive industry. Thereby, reducing vehicle weight and costs have increasing importance. However, since there are requirements to achieve greater engine power, the price factor and legislation on vehicle recycling, it is necessary to find a compromise, primarily between weight and acoustic comfort, power, price and regulations.

Today, the acoustics in the passenger compartment is one of the most important performance of vehicles. Noise inside the vehicle has a central role and it suppresses the effects of other vehicle characteristics. Thus, when the noise is unpleasant, the impression of a quality vehicle is lost. Automotive manufactures are paying special attention to reduction of vehicle noise. For example, over several decades, Japan's automakers have introduced new technologies into their products to reduce vehicle noise. Because of those efforts, the vehicles they manufacture today are extremely quiet. Compared to the levels in 1971, when regulations in this area were first introduced in Japan, heavy-truck noise has been reduced by $92 \%$, passenger car noise by $83 \%$ and motorcycle noise by $95 \%$ [6].

Over the years, vehicle interior noise is significantly reduced in response to customer expectations. In the last 40 years, the greatest improvements were observed in reducing differences in the levels of internal noise between family and luxury vehicles. Unlike external noise, it is believed that the existence of internal noise is advisable to make an impression on the character of the vehicle and as indication of the speed of the vehicle. Some modern luxury, electric and hybrid vehicles have even gone below the ideal noise limits. In fact, they are too quiet.

Although there was knowledge that prolonged exposure to noise causes hearing loss, there have been no proposals of standards in relation to noise exposure limits until 1950s. The US Air Force approved the first standard on noise exposure in the United States in 1956. Research bodies and committees for adoption of standards had discussed the issues of noise for more than a decade, before the exposure limits to noise have entered the legislature [7]. 
International Organization for Standardization (ISO) and its Technical Committee 43 (ISO/TC 43) are dealing with global acoustics problems, some of which are related to vehicle noise problems. United Nations Economic Commission for Europe (UNECE) has also published a series of regulations on vehicle noise, starting from Directive 70/157/EEC in 1970.

Institute for standardization of Serbia (ISS), as a national body for standardization, has adopted a set of standards on noise emitted by motor vehicles, which are identical to corresponding regional standards in European Union (EN standards), European standards based on international standards (EN ISO standards) or international standards (ISO standards). In addition, Serbian "Regulation on division of motor vehicles and trailers and technical requirements for vehicles in road traffic" defines the limits for allowed exterior noise emitted by motor vehicles.

\section{INTERNATIONAL REGULATIONS ON ROAD VEHICLE NOISE}

The most important international organizations that publish standards on measurement and analysis of noise are International Electro technical Commission (IEC) and International organization for standardization (ISO). IEC is responsible for design of instruments for noise measurement noise, while ISO, as the holder of standardization, is competent in the fields of measurement techniques, experimental conditions, measurement parameters and limits for the measurement results.

\subsection{ISO standards}

International organization for standardization (ISO) is the worldwide federation of national bodies for standardization. The preparation of international standards is conducted through numerous technical committees. ISO closely cooperates with International electrotechical commission on all problems of standardization in the area of electrotechical engineering.

ISO and its Technical committee 43 - Acoustics, Sub-committee 1 - Noise (ISO/TC 43/SC 1) deal with global problems of noise in 111 standards published and 23 standards currently under development. The ISO/TC 43/SC 1 standards that are related directly to noise emitted by road vehicles are shortly described in Table 1.

The following ISO/TC 43/SC 1 standards deal with the influence of road surfaces on traffic noise:

- ISO 10844:2014 - Acoustics - Specification of test tracks for measuring noise emitted by road vehicles and their tyres

- ISO 11819-1:1997 - Acoustics - Measurement of the influence of road surfaces on traffic noise - Part 1: Statistical Pass-By method

- ISO/PAS 11819-4:2013 - Acoustics - Method for measuring the influence of road surfaces on traffic noise - Part 4: SPB method using backing board

- ISO 13472-1:2002 - Acoustics - Measurement of sound absorption properties of road surfaces in situ - Part 1: Extended surface method and

- ISO 13472-2:2010 - Acoustics - Measurement of sound absorption properties of road surfaces in situ - Part 2: Spot method for reflective surfaces. 
Table 1: ISO/TC 43/SC 1 standards directly related to noise emitted by road vehicles

\begin{tabular}{|c|c|}
\hline ISO/TC 43/SC 1 standard & Brief description \\
\hline $\begin{array}{c}\text { ISO 362-1:2015 - Measurement of } \\
\text { noise emitted by accelerating road } \\
\text { vehicles - Engineering method - Part 1: } \\
\text { M and } N \text { categories }\end{array}$ & $\begin{array}{l}\text { - specifies an engineering method for measuring } \\
\text { noise of road vehicles of categories } \mathrm{M} \text { and } \mathrm{N} \\
\text { under typical urban traffic conditions }\end{array}$ \\
\hline $\begin{array}{c}\text { ISO 362-2:2009 - Measurement of } \\
\text { noise emitted by accelerating road } \\
\text { vehicles - Engineering method - Part 2: } \\
\text { L category }\end{array}$ & $\begin{array}{c}\text { - specifies an engineering method for measuring } \\
\text { noise of road vehicles of categories L3, L4 and L5 } \\
\text { under typical urban traffic conditions }\end{array}$ \\
\hline $\begin{array}{c}\text { ISO 362-3:2016 - Measurement of } \\
\text { noise emitted by accelerating road } \\
\text { vehicles - Engineering method - Part 3: } \\
\text { Indoor testing M and N categories }\end{array}$ & $\begin{array}{c}\text { - specifies an engineering method for measuring } \\
\text { noise of road vehicles of categories } \mathrm{M} \text { and } \mathrm{N} \text { by } \\
\text { using a semi anechoic chamber }\end{array}$ \\
\hline $\begin{array}{c}\text { ISO 5128:1980 - Acoustics - } \\
\text { Measurement of noise inside motor } \\
\text { vehicles }\end{array}$ & $\begin{array}{l}\text { - specifies the conditions for obtaining } \\
\text { reproducible and comparable data of noise levels } \\
\text { and spectra inside road vehicles (excluding } \\
\text { agricultural tractors and field machinery) }\end{array}$ \\
\hline $\begin{array}{l}\text { ISO 5130:2007 - Acoustics - } \\
\text { Measurements of sound pressure level } \\
\text { emitted by stationary road vehicles }\end{array}$ & $\begin{array}{l}\text { - specifies conditions for measuring the exterior } \\
\text { sound pressure levels from stationary road } \\
\text { vehicles, with continuous measurement of the } \\
\text { sound pressure level over a range of engine } \\
\text { speeds; } \\
\text { - applies only to road vehicles of categories L, M } \\
\text { and N equipped with internal combustion engines }\end{array}$ \\
\hline $\begin{array}{l}\text { ISO 9645:1990 - Acoustics - } \\
\text { Measurement of noise emitted by two- } \\
\text { wheeled mopeds in motion - } \\
\text { Engineering method }\end{array}$ & $\begin{array}{l}\text { - specifies an engineering method for measuring } \\
\text { noise of two-wheeled mopeds in motion in urban } \\
\text { traffic flow of irregular character, with full use of } \\
\text { the available engine power }\end{array}$ \\
\hline $\begin{array}{c}\text { ISO 16254:2016 - Acoustics - } \\
\text { Measurement of sound emitted by road } \\
\text { vehicles of category M and N at } \\
\text { standstill and low speed operation - } \\
\text { Engineering method }\end{array}$ & $\begin{array}{l}\text { - specifies an engineering method for measuring } \\
\text { the sound emitted by } \mathrm{M} \text { and } \mathrm{N} \text { category road } \\
\text { vehicles' principal sound sources in stationary } \\
\text { and low speed vehicle operating conditions } \\
\text { relevant for pedestrian safety; } \\
\text { - derived from ISO 362-1 }\end{array}$ \\
\hline
\end{tabular}

Some of the standards from this category, also related to influence of road surfaces on traffic noise are currently under development:

- ISO/DIS 11819-2.2 - Acoustics - Measurement of the influence of road surfaces on traffic noise - Part 2: The close-proximity method and

- ISO/DTS 11819-3 - Acoustics - Measurement of the influence of road surfaces on traffic noise - Part 3: Reference tyres. 
The tyre/road noise is the subject of one standard published by ISO/TC 43/SC 1 :

- ISO/CD 13471-1 Acoustics -- Temperature influence on tyre/road noise measurement -- Part 1: Correction for temperature when testing with the CPX method while ISO Technical committee 31 - Tyres, rims and valves (ISO/TC 31) has one published standard related to tyre/road noise:

- ISO 13325:2003 - Tyres - Coast-by methods for measurement of tyre-to-road sound emission

and one standard in development stage:

- ISO/NP 20908 - Tyre noise test - Methods of drum.

All mentioned ISO standards dealing with road vehicle noise provide necessary information on measurement techniques and equipment to be applied, experimental conditions to be met, measurement parameters to be taken into account and the limits for the measurement results.

\subsection{UNECE regulations}

United Nation's Economic Commission for Europe (UNECE) has published a series of 137 regulations as addenda to the 1958 Agreement ("Agreement concerning the adoption of uniform technical prescriptions for wheeled vehicles, equipment and parts which can be fitted and/or be used on wheeled vehicles and the conditions for reciprocal recognition of approvals granted on the basis of these prescriptions"). The following UNECE regulations are related to road vehicle noise:

- Regulation No. 9 (UN/ECE R9) - Uniform provisions concerning the approval of category L2, L4 and L5 vehicles with regard to noise

- Regulation No. 41 (UN/ECE R41) - Uniform provisions concerning the approval of motor cycles with regard to noise

- Regulation No. 51 (UN/ECE R51) - Uniform provisions concerning the approval of motor vehicles having at least four wheels with regard to their sound emissions

- Regulation No. 63 (UN/ECE R63) - Uniform provisions concerning the approval of two-wheeled mopeds with regard to noise

- Regulation No. 117 (UN/ECE R117) - Uniform provisions concerning the approval of tyres with regard to rolling sound emissions and to adhesion on wet surfaces and/or to rolling resistance.

After a 15-year-long discussion, UNECE Working party on noise (GRB) has finally reached agreement on the third series of amendments to regulation UN/ECE R51 (UN/ECE R51.03) in September 2014. Regulation UN/ECE R51.03 was adopted by the UN World forum for harmonization of vehicle regulations (WP.29) in June 2015. It will enter into force in three phases, starting from 20 January 2016.

Regulation UN/ECE R51.03 has introduced a transition from emphasis on powertrain to total vehicle test (including the tyres). It contains the most recent decibel limit values for all types of road vehicles with at least four wheels, presented in Table 2 [8].

For vehicles with low and medium power engines, the limit values are already lower than $74 \mathrm{~dB}(\mathrm{~A})$, which is a long standing limit. In later phases, in 2020 and 2024, these limits will be decreased considerably. New measurement procedures and considerably reduced pass-by-noise limit values will be, certainly, a great challenge to automotive industry in the world. 
Table 2: Limit values for pass-by noise of road vehicles with at least four wheels according to GRB [8]

\begin{tabular}{|c|c|c|c|c|}
\hline \multirow[b]{2}{*}{$\begin{array}{l}\text { Vehicle } \\
\text { category }\end{array}$} & \multirow[b]{2}{*}{$\begin{array}{l}\text { Vehicle used for the carriage of } \\
\text { passengers }\end{array}$} & \multicolumn{3}{|c|}{ Limit values expressed in $\mathrm{dB}(\mathrm{A})$} \\
\hline & & $\begin{array}{c}\text { Phase } 1 \\
\text { applicable } \\
\text { for new } \\
\text { vehicle types } \\
\text { from } 1 \text { July } \\
2016\end{array}$ & $\begin{array}{c}\text { Phase } 2 \\
\text { applicable } \\
\text { for new } \\
\text { vehicle type } \\
\text { from } 1 \text { July } \\
2020 \text { and for } \\
\text { first } \\
\text { registration } \\
\text { from } \\
1 \text { July } 2022\end{array}$ & $\begin{array}{c}\text { Phase } 3 \\
\text { applicable } \\
\text { for new } \\
\text { vehicle type } \\
\text { from } 1 \text { July } \\
2024 \text { and for } \\
\text { first } \\
\text { registration } \\
\text { from } \\
1 \text { July } 2026\end{array}$ \\
\hline \multirow{4}{*}{ M1 } & $\begin{array}{c}\text { power to mass ratio } \leq 120 \\
\mathrm{~kW} / 1000 \mathrm{~kg}\end{array}$ & $72^{(1)}$ & $70^{(1)}$ & $68^{(1)}$ \\
\hline & $\begin{array}{c}120 \mathrm{~kW} / 1000 \mathrm{~kg}<\text { power to } \\
\text { mass ratio } \leq \\
160 \mathrm{~kW} / 1000 \mathrm{~kg}\end{array}$ & 73 & 71 & 69 \\
\hline & $\begin{array}{c}160 \mathrm{~kW} / 1000 \mathrm{~kg}<\text { power to } \\
\text { mass ratio }\end{array}$ & 75 & 73 & 71 \\
\hline & $\begin{array}{c}\text { power to mass ratio }>200 \mathrm{~kW} / 1 \\
000 \mathrm{~kg} \\
\text { number of seats } \leq 4 \\
\mathrm{R} \text { point of driver seat } \leq 450 \mathrm{~mm} \\
\text { from the ground }\end{array}$ & 75 & 74 & 72 \\
\hline \multirow{4}{*}{ M2 } & mass $\leq 2500 \mathrm{~kg}$ & 72 & 70 & 69 \\
\hline & $2500 \mathrm{~kg}<\operatorname{mass} \leq 3500 \mathrm{~kg}$ & 74 & 72 & 71 \\
\hline & $\begin{array}{l}3500 \mathrm{~kg}<\text { mass } \leq 5000 \mathrm{~kg} \\
\text { rated engine power } \leq 135 \mathrm{~kW}\end{array}$ & 75 & 73 & 72 \\
\hline & $\begin{array}{l}3500 \mathrm{~kg}<\text { mass } \leq 5000 \mathrm{~kg} ; \\
\text { rated engine power }>135 \mathrm{~kW}\end{array}$ & 75 & 74 & 72 \\
\hline \multirow{3}{*}{ M3 } & rated engine power $\leq 150 \mathrm{~kW}$ & 76 & 74 & $73^{(2)}$ \\
\hline & $\begin{array}{c}150 \mathrm{~kW}<\text { rated engine power } \leq \\
250 \mathrm{~kW}\end{array}$ & 78 & 77 & $76^{(2)}$ \\
\hline & rated engine power $>250 \mathrm{~kW}$ & 80 & 78 & $77^{(2)}$ \\
\hline $\begin{array}{l}\text { Vehicle } \\
\text { category }\end{array}$ & $\begin{array}{l}\text { Vehicle used for the carriage of } \\
\text { goods }\end{array}$ & $\begin{array}{c}\text { Phase } 1 \\
\text { applicable } \\
\text { for new } \\
\text { vehicle types } \\
\text { from } \\
\text { 1 July } 2016\end{array}$ & $\begin{array}{c}\text { Phase } 2 \\
\text { applicable } \\
\text { for new } \\
\text { vehicle type } \\
\text { from } \\
\text { 1 July } 2020 \\
\text { and for first } \\
\text { registration }\end{array}$ & $\begin{array}{c}\text { Phase } 3 \\
\text { applicable } \\
\text { for new } \\
\text { vehicle type } \\
\text { from } \\
1 \text { July } 2024 \\
\text { and for first } \\
\text { registration }\end{array}$ \\
\hline
\end{tabular}




\begin{tabular}{|c|c|c|c|c|}
\hline \multirow{2}{*}{ N1 } & mass $\leq 2500 \mathrm{~kg}$ & 72 & $\begin{array}{c}\text { from } \\
1 \text { July 2022 }\end{array}$ & $\begin{array}{c}\text { from } \\
1 \text { July 2026 }\end{array}$ \\
\cline { 2 - 5 } & $2500 \mathrm{~kg}<$ mass $\leq 3500 \mathrm{~kg}$ & 74 & 71 & 69 \\
\hline \multirow{3}{*}{$\mathrm{N} 2$} & rated engine power $\leq 135 \mathrm{~kW}$ & 77 & 73 & 71 \\
\cline { 2 - 5 } & rated engine power $>135 \mathrm{~kW}$ & 78 & $76^{(2)}$ & $74^{(2)}$ \\
\hline \multirow{3}{*}{$\mathrm{N} 3$} & rated engine power $\leq 150 \mathrm{~kW}$ & 79 & 77 & $75^{(2)}$ \\
\cline { 2 - 5 } & $150 \mathrm{~kW}<$ rated engine power $\leq$ & 81 & 79 & $76^{(2)}$ \\
\cline { 2 - 5 } & rated engine power $>250 \mathrm{~kW}$ & 82 & 81 & $79^{(2)}$ \\
\hline
\end{tabular}

(1) M1 vehicles derived from N1 vehicles: $M 1$ vehicles with an $R$ point $>850 \mathrm{~mm}$ from the ground and a total permissible laden mass more than $2500 \mathrm{~kg}$ have to fulfil the limit values of $\mathrm{N1}(2500 \mathrm{~kg}<$ mass $\leq 3500 \mathrm{~kg})$.

(2) + two years for new vehicle type and + one year for new vehicles registration

\section{Problem with „silent vehicles“}

Noise emitted by road vehicle is used to detect presence of the vehicle, to assess its speed or decide whether the vehicle is accelerating or decelerating. However, hybrid and electrical vehicles do not emit significant levels of noise and they may be a safety risk for blind or visually impaired people, pedestrians or cyclists. The expanding share of these vehicles on today's market has brought the danger of their quietness while running at low speed.

The problem of so-called "silent vehicles" is addressed by a new regulation adopted by the UNECE World Forum for Harmonization of Vehicle Regulations (WP.29) „Regulation on Quiet Road Transport Vehicles (QRTV)”. This Regulation requires implementation of acoustic warning devices on hybrid and electric vehicles. The goal of the regulation is to minimize the risk posed by silent vehicles [9].

The new Regulation demands that quiet vehicles should be equipped with an Acoustic Vehicle Alerting System (AVAS) to create artificial noise in the speed range from 0 to $20 \mathrm{~km} / \mathrm{h}$. The tyre/road noise and wind noise are audible at speeds above $20 \mathrm{~km} / \mathrm{h}$, so there is no need for artificial noise in this range of vehicle speed. The Regulation introduces the minimum AVAS sound pressure levels and spectrum and frequency shift, depending on the vehicle's speed. When the car's speed increases, the sound becomes louder so that pedestrians can audibly judge the speed. At this stage, the Regulation covers only acoustic measures to overcome the concerns of reduced audible signals from electrified vehicles. In the future, the Regulation should encompass other, non-acoustic measures, such as pedestrian detection systems within the vehicle [10].

\subsection{European regulations}

Activities to be implemented throughout Europe in order to reduce environmental noise have a different priority compared to ecological problems such as air and water pollution, often because it was thought that such issues are best handled at national or local level. Since information on the impact of noise on human health are increasingly available, there is more pronounced need for a higher level of protection of EU citizens against noise through a wider framework of measures in all of Europe. 
The European Union (EU) and the European free trade association (EFTA) have officially recognized the European committee for standardization (CEN) as one of three European standardization organizations (together with CENELEC - European committee for electrotechnical standardization and ETSI - European telecommunications standards institute) responsible for development of European voluntary standards. CEN brings together the national standardization bodies of 33 European countries and supports standardization activities in relation to a wide range of fields, including transport. European standards (ENs) approved by CEN and CENELEC are accepted and recognized in all of member countries. However, most standards related to road transport are defined at global (international) level, so CEN coordinates its activities in this field with activities of ISO [11]. Recent standardization activities of CEN do not include projects related to road vehicle noise.

In Europe, control of exterior noise emitted by road vehicles is conducted through procedures of the type-approval of the vehicle. Each new type of vehicle on the market must fulfil demands published in legislation. In 1970, the former European Economic Community adopted Directive 70/157/EEC, which has introduced permissible noise levels for all motor vehicles with at least four wheels travelling with maximum speed of more than $25 \mathrm{kmh}^{-1}$ (cars, trucks, buses). It has been adjusted by the laws of the member states concerning the permissible noise levels and exhaust systems of motor vehicle and has undergone several amendments in the field of noise limits and measuring methods:

- 77/212/EEC - change in vehicle categories and introduction of decreased noise limits

- $\quad 81 / 334 /$ EEC - amendments to the method of measuring the noise of moving and stationary vehicles in order to get them closer to the actual operating conditions

- 84/372/EEC - amendments to the method of measuring the noise emitted by highperformance vehicles and vehicles with automatic transmissions with manual adjustments in order to get them closer to the actual operating conditions

- $84 / 424 /$ EEC - replacement of noise limit values by lower values for all categories of vehicles

- 92/97/EEC - comprehensive amendments by reduction of the noise level limits for all categories of vehicles and by improving the test method for vehicles with large engine power, because this type of vehicle is increasingly designed in such way that it has a higher power-to-mass (PTM) ratio of the vehicle and the curve representing the engine torque as a function of the engine speed was changed to produce a greater driving force at low engine speeds; new designs have increased the use of gear lever in urban traffic and have a major impact on the noise emitted by the mechanical parts of the vehicle as compared to road noise

- 2007/34/EC - introduction of a new test cycle, which gets demanded driving conditions nearer to actual driving conditions (as described in UN/ECE R51.02).

Regulation EU 540/2014 on the sound level of motor vehicles and of replacement silencing systems of the European Parliament and of the Council of Europe has repealed the Directive 70/157/EEC in 2014. Reason behind this event is in the fact that, despite the increased traffic, EU noise emission limits have not changed for more than 20 years. Thus, the European commission has proposed to reduce the noise produced by passenger cars, light commercial vehicles, buses, light trucks, coaches, and trucks in hope to reduce road vehicle noise by around $25 \%$. The new regulation has introduced [12]:

- new test method that better reflects current driving behaviour

- lower noise limit values 
- additional sound emission provisions (ASEP), which will be included in typeapproval procedure as preventive requirements intended to cover driving conditions in real traffic, ensuring that the noise of a vehicle under street driving conditions does not significantly differ from vehicle noise when it is tested

- a specific Annex on minimum noise of electric and hybrid electric vehicles and

- noise labelling in order to foster competition with manufacturers displaying the sound level of each vehicle during sale.

To illustrate how noise limits have changed by European directives in last several decades, Figure 1 presents trends in pass-by-noise limit values for passenger vehicles, as they have been altered through years and expected future values. In the future, the limit values for M1 type of vehicles will be lowered in two steps of $2 \mathrm{~dB}(\mathrm{~A})$ each.

For $\mathrm{N} 3$ types of vehicles with rated engine power below $250 \mathrm{~kW}$, limits will be lowered by $2 \mathrm{~dB}(\mathrm{~A})$ in two steps, while for $\mathrm{N} 3$ types of vehicles with rated engine power above $250 \mathrm{~kW}$, the reduction will be $1 \mathrm{~dB}(\mathrm{~A})$ for the first step and $2 \mathrm{~dB}(\mathrm{~A})$ for the second step, Figure 2.

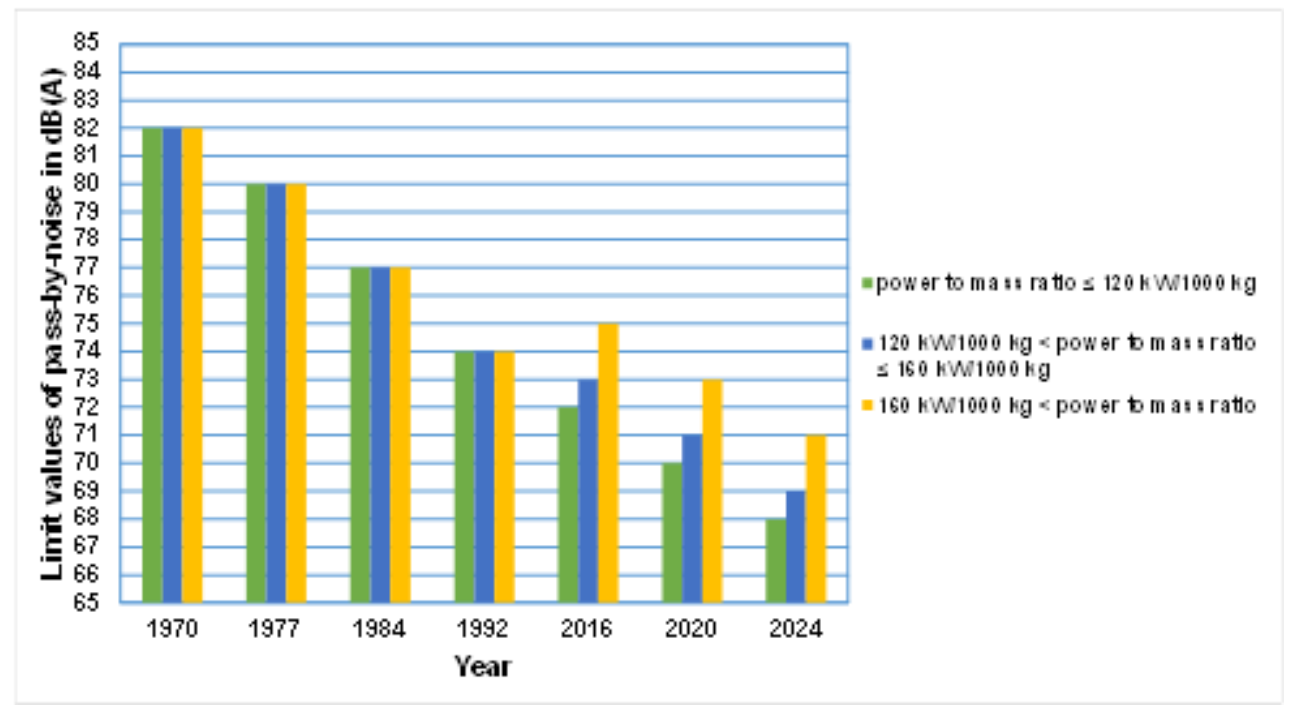

Figure 1 Trends in pass-by-noise limit values for M1 type of vehicles in European directives 


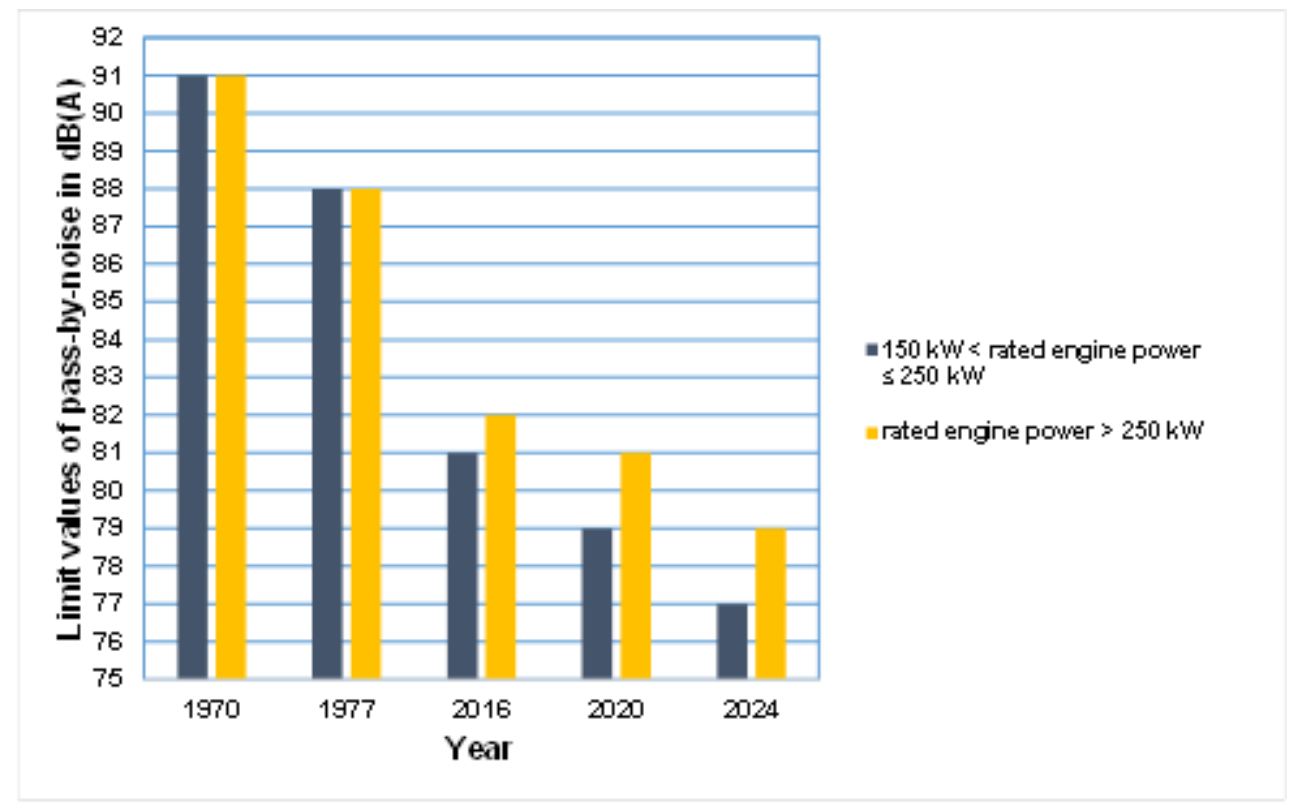

Figure 2 Trends in pass-by-noise limit values for N3 type of vehicles in European directives

\section{ROAD VEHICLE NOISE IN SERBIAN REGULATIONS}

Institute for standardization of Serbia (ISS), as a national body for standardization, has adopted a set of Serbian standards (SRPS) on noise emitted by motor vehicles, which are identical to corresponding European standards based on international standards (EN ISO standards) or international standards (ISO standards). The following SRPS standards are directly related to problems of road vehicle noise:

- $\quad$ SRPS EN ISO 11819-1:2012 - Acoustics - Measurement of the influence of road surfaces on traffic noise - Part 1: Statistical Pass-By method (ISO 11819-1:1997)

- SRPS ISO 362-1:2015 - Measurement of noise emitted by accelerating road vehicles - Engineering method - Part 1: $\mathrm{M}$ and $\mathrm{N}$ categories

- $\quad$ SRPS ISO 5128:2015- Acoustics - Measurement of noise inside motor vehicles.

Serbian "Regulation on classification of motor vehicles and trailers and technical requirements for vehicles in road traffic" [13] deals with problems of motor vehicle noise in its Article 78. According to this Article, the limit values of allowed exterior noise for each type of vehicle, measured in laboratory conditions, are presented in Table 3. 
Table 3 Limit values of allowed exterior noise emitted by road vehicles in laboratory conditions [13]

\begin{tabular}{|c|c|}
\hline Vehicle category & $\begin{array}{c}\text { Limit value } \\
\text { of noise in } \\
\text { dB(A) }\end{array}$ \\
\hline L1 & 81 \\
\hline L3 with two-stroke engines with engine capacity not higher than $125 \mathrm{~cm} 3$ & 85 \\
\hline L3 with two-stroke engines with engine capacity higher than $125 \mathrm{~cm} 3$ & 87 \\
\hline L3 with four-stroke engines with engine capacity not higher than $125 \mathrm{~cm} 3$ & 85 \\
\hline L3 with four-stroke engines with engine capacity from $125 \mathrm{~cm} 3$ to 500 & 87 \\
cm3 & 89 \\
\hline L3 with four-stroke engines with engine capacity higher than $500 \mathrm{~cm} 3$ & 88 \\
\hline Three-wheeled vehicles & \\
\hline L2, L4, L5 & 87 \\
\hline Motor vehicles with at least four wheels & 88 \\
\hline M2 and N1 & 92 \\
\hline M3, N2 and N3 and with engine rated power not higher than $147 \mathrm{~kW}$ & 95 \\
\hline M3, N2 and N3 and with engine rated power higher than $147 \mathrm{~kW}$ & \\
\hline
\end{tabular}

Exterior noise is measured according to the method for measurement of noise of stationary vehicle. Articles of this Regulation do not apply to vehicles produced or registered for the first time before January 1st, 1972 and to military vehicles.

Another Serbian Regulation - "Regulation on technical and technical-exploitation requirements that must be met by trucks and busses conducting international public transport in road traffic" [14] sets the technical requirements regarding noise and pollutant emissions and technical-exploitation requirements regarding safety that must be met by trucks, trailers and buses, which conduct international public transport in road traffic. According to this Regulation, and consistent with provided Certificates of fulfilment of technical requirements in terms of noise and pollutant emissions, the heavy-duty vehicles are divided into the following categories:

- "Green"

- "Greener and safe"

- "EVRO III safe"

- $\quad$ "EVRO IV safe"

- $\quad$ "EVRO V safe"

- $\quad$ "EVRO EEV safe" and

- $\quad$ "EVRO VI safe".

Serbian „Low on safety and health at work“ [15] states that, until regulations on general and specific safety and health measures are not set, measures for safety at work will be applied which are contained by „Regulation on measures and norms of protection at work 
against noise in work areas" [16]. This Regulation sets the occupational noise thresholds in relation to the type of work. For physical work focused on precision and concentration with intermittent assessment and control of environment by hearing and for control of transport devices, the threshold limits are:

- $\quad 80 \mathrm{~dB}(\mathrm{~A})$ for noise made by device operated by worker and

- $70 \mathrm{~dB}(\mathrm{~A})$ for noise emitted by non-production sources (like street traffic).

Also, according to „The low on safety and health at work“, articles of "Regulation on occupational safety during motor vehicle maintenance and motor vehicle transport" may also be applied until regulations on general and specific safety and health measures are not set (if not in collision with the Low). This Regulation states that, during operation of engine, noise inside the vehicle dedicated to carry passengers and crew must not exceed $80 \mathrm{~dB}$ [17].

\section{CONCLUSIONS}

Noise is inevitable companion of accelerated technological development. In today's society, there is a constant need to pay attention to noise protection, because noise is one of the most frequent ecological problems in the community. Road traffic noise, in particular, presents a very complex noise source, both in and out of urban areas. It is a product of effects of a number of factors: vehicle noise and driving practices, road structure, road surface quality, the traffic flow and factors of the roadside environment. Based on measurements of noise levels and traffic parameters and their analysis, it is noticed that the approach of individual analysis of each factor and assessment of their contribution to the total noise levels may lead to wrong conclusions. Thus, comprehensive measures must be introduced in order to address the multiple challenges involved in effective road traffic noise reduction.

Very important actions are taken on international level in order to decrease the traffic noise. Corresponding technical regulations and international standards are developed and adopted in this field. Most European regulations are focused on reducing the traffic noise at the source - by applying measures on newly produced vehicles. More and more strict limits are established for noise of vehicle engines and exhausts. Quieter types of vehicles are promoted and low-noise road surfaces are developed. There are some opinions that stricter vehicle noise standards are so cost-effective that 100 times more people can be protected from road noise for every Euro spent on development and production of quitter vehicles instead of on application of noise barriers and sound insulation.

Problem of road vehicle exterior noise should attract greater attention. It is necessary to monitor traffic noise levels emitted by each of vehicle categories, continually, during longer periods (couple of years) in order to take a stand about fulfilment of requirements and standards defined by authorized bodies. In addition, measures to be taken in addressing tire-road noise reduction and development of quiet road surfaces will play an important role in meeting the environmental standards in the future.

\section{ACKNOWLEDGMENT}

Research presented in this paper was conducted within the framework of the project TR35041, "Research of vehicle safety as a part of cybernetics system Driver Vehicle - Environment", financi0ally supported by the Ministry of education, science and technology of the Republic of Serbia. 


\section{REFERENCES}

[1] Kotzen, B., English, C.: "Environmental noise barriers", 2009, Taylor \& Francis, Abingdon.

[2] Whitelegg, J.: "Health of professional drivers - A report for Transport \& General workers union", 1995, Eco-logica Ltd., Lancaster.

[3] The European Parliament and the Council of the European Union: "Directive 2002/49/EC of the European Parliament and of the Council of 25 June 2002 relating to the assessment and management of environmental noise", 2002, Official Journal of the European Union, L 189/12 - L 189/25.

[4] The European Environment Agency: "Noise in Europe 2014", EEA Report No 10/2014, 2014, Publications Office of the European Union, Luxembourg.

[5] The European Environment Agency: "Evaluating 15 years of transport and environmental policy integration - TERM 2015: Transport indicators tracking progress towards environmental targets in Europe”, EEA Report No 7/2015, 2015, Publications Office of the European Union, Luxembourg.

[6] JAMA - Japan automobile manufacturers association, Inc.: "2016 Report on environmental protection efforts - Promoting sustainability in road transport in Japan", 2016, JAMA, Tokyo.

[7] Miloradovic, D., Todorovic, P.: "Chapter 12: Physical hazards - Occupational noise (in Serbian)", "Safety and health at work - Book 2" (Jankovic, A., Jermic, B. eds.), 2009, BZR Educational centre, Faculty of mechanical engineering Kragujevac, Kragujevac, pp. 457-502.

[8] ECE World Forum for Harmonization of Vehicle Regulations - Working Party on Noise: "Proposals for the 03 series of amendments to Regulation No. 51 (Noise of M and N categories of vehicles)", 2015, UNECE, Geneva.

[9] The United Nations Economic Commission for Europe: "New UN Regulation keeps silent cars from becoming dangerous cars", Published: 09 March 2016, Accessed: 20 June 2016, Available at: http://www.unece.org/info/media/presscurrent-press$\mathrm{h} /$ transport/2016/new-un-regulation-keeps-silent-cars-from-becoming-dangerouscars/doc.html.

[10] ECE World Forum for Harmonization of Vehicle Regulations - Working Party on Noise: "Proposal for a new Regulation concerning the approval of quiet road transport vehicles (QRTV)", 2016, UNECE, Geneva.

[11] CEN \& CENELEC: "Work programme 2014 - European Standardization and related activities", 2014, Sarah Penny - CEN \& CENELEC, Brussels.

[12] The European Parliament and the Council of the European Union: "Regulation (EU) No. 540/2014 of the European Parliament and of the Council of 16 April 2014 on the sound level of motor vehicles and of replacement silencing systems, and amending Directive 2007/46/EC and repealing Directive 70/157/EEC", 2014, Official Journal of the European Union, L 158/131 - L 158/195.

[13] The Government of the Republic of Serbia: "Regulation on classification of motor vehicles and trailers and technical requirements for vehicles in road traffic", 2016, Official Gazette of the Republic of Serbia, No. 40/2012, 102/2012, 19/2013, 41/2013, 102/2014, 41/2015, 78/2015, 111/2015 and 14/2016, Belgrade.

[14] The Government of the Republic of Serbia: "Regulation on technical and technicalexploitation requirements that must be met by heavy-duty vehicles and busses conducting international public transport in road traffic", 2013, Official Gazette of the Republic of Serbia, No. 73/2013, Belgrade. 
[15] The Government of the Republic of Serbia: „The low on safety and health at work“, 2015, Official Gazette of the Republic of Serbia, No. 101/2005 and 91/2015, Belgrade.

[16] The Government of the Socialist Federal Republic of Yugoslavia: "Regulation on measures and norms of protection at work against noise in work areas“, 1992, Official Gazette of the Socialist Federal Republic of Yugoslavia, No. 21/92, Belgrade.

[17] The Government of the Socialist Federal Republic of Yugoslavia: "Regulation on occupational safety during motor vehicle maintenance and motor vehicle transport", 1965, Official Gazette of the Socialist Federal Republic of Yugoslavia, No. 55/65, Belgrade. 